\title{
How Country Affects the Capital Structure Choice: Literature Review and Criticism
}

\author{
Daniela Venanzi ${ }^{1}$ \\ ${ }^{1}$ Department of Economics, Roma Tre University, Rome, Italy \\ Correspondence: Daniela Venanzi, Department of Economics, Roma Tre University, Via Silvio D’Amico 77, \\ 00145 Rome, Italy. Tel: 39-06-5733-5637. E-mail: daniela.venanzi@uniroma3.it
}

Received: January 26, 2017

Accepted: February 18, 2017

Online Published: March 10, 2017

doi:10.5539/ijef.v9n4p1

URL: https://doi.org/10.5539/ijef.v9n4p1

\begin{abstract}
Recent international financial research finds that not only firm- and industry-specific determinants, but also country-specific factors influence a firm's capital structure. The paper's aim is twofold. Firstly, it proposes a systematic view of the international studies on country effect since 2000 , by highlighting both similarities and differences in terms of tested hypotheses, country-level determinants, expected relationships. The main outcome is a complete framework of the country characteristics, which mostly affect the capital structure choice as well as their respective theoretical rationale. Secondly, based on the above review, some areas of potential development in empirical testing will be identified, regarding test design, sample selection, dependent variable measurement, statistical methodology: the paper's objective is to critically discuss the state of the art in this field, to hopefully improve the empirical testing of country effect on leverage in further research.
\end{abstract}

Keywords: capital structure, country effect, literature review, criticisms on empirical testing

\section{Introduction}

The choice of capital structure is a hot issue in international financial research. Since the Modigliani-Miller (1958) seminal contribution, many theories have been formulated and many empirical studies implemented. However, ample space for further research remains, since the empirical evidence does not always support the theoretical hypotheses and often stimulates the formulation and testing of new hypotheses.

In this context, the country effect on corporate financial leverage seems to be a good candidate for further analysis. Prior research (e.g., Rajan \& Zingales, 1995; Demirguc-Kunt \& Maksimovic, 1999; Booth et al., 2001; Giannetti, 2003; Hall et al., 2004; Bancel \& Mittoo, 2004; Antoniou et al., 2008; de Jong et al., 2008; Aggarwal \& Kyaw, 2009; Alves \& Ferreira, 2011; Kayo \& Kimura, 2011; Fan et al., 2012; Acedo-Ramirez \& Ruiz-Cabestre, 2014) finds that a firm's capital structure is not only influenced by firm- and industry-specific determinants, but also by country-specific factors: many country characteristics, such as the macroeconomic context, the institutional framework and the financial system, seem to affect (directly and indirectly) a firm's capital structure.

This paper briefly reviews most of the international studies on country effect since 2000 and identifies some areas of potential development in empirical testing. The critical issues that should be taken in account in further research refers to the sample selection, how the country effect is analyzed (by breaking down the country effect in an ample set of respective characteristics or simply using country dummies), how it is caught (only directly or indirectly too, in terms of mediating role of the impact of firm-specific determinants), how leverage is measured, and so on.

The paper is therefore organized as follows. Section 2 presents an overview of the most recent international literature on country effect, that allows to build a general framework of the country characteristics usually included in the explanatory model of leverage, and the theoretical reasons underlying their expected impact on capital structure choice. Based on this review, Section 3 highlights some areas of useful improvement of the test design, to better measure the country effect.

\section{The Country Effect on the Choice of Corporate Capital Structure: An Overview of the Recent Empirical Literature}

Except for the pioneering study by Rajan and Zingales (1995), only from 2000 the international literature 
analyzed the role of countries as a determinant of firm leverage (Booth et al., 2001; Giannetti, 2003; Hall et al., 2004; Antoniou et al., 2008; de Jong et al., 2008; Aggarwal \& Kyaw, 2009; Alves \& Ferreira, 2011; Kayo \& Kimura, 2011; Fan et al., 2012; Acedo-Ramirez \& Ruiz-Cabestre, 2014).

Table 1 summarizes the relevant features of these empirical studies (from here on acronyms are used).

The main recent studies adopt a causal determinants-leverage explanatory approach, using large samples, which include many countries, differing in development stage of the economy (developed and developing countries), type of financial systems (bank- and market-based), and institutional environments (common and civil law countries, and related law and order frameworks). The country determinants are generally associated with firm-specific determinants (very similar across studies), and more rarely with industry-specific variables (G, AGP and KK), often omitted or simply included as industry dummies (fixed industry effect), no matter which characteristics they differ in.

The country effect is generally measured including many country characteristics (institutional framework, financial system, and macro-economic scenario) as regressors of leverage. Only a few studies include in the empirical test the country dummies, omitting a more explicit characterization.

Almost all studies (AK and FTT are exceptions) measure both the direct and the indirect country effect on leverage, the latter being the influence of country characteristics on the impact on leverage of the non-country determinants (especially the firm-specific variables). The actual difference among these studies consists in the way they identify and measure these two effects.

Both effects can be included in the explanatory model of leverage disaggregating the country impact in its components (the country's key characteristics) or, on the contrary, measuring it in aggregate terms. The latter studies either include in the model country dummies or country fixed effects, or estimate country by country independent regressions, without interacting firm-specific determinants with country characteristics, and only ex post rationalizing the different parameter estimates across countries.

The various studies use panel data and estimate regression models to explain both the longitudinal and the cross-sectional variability of leverage, including the time fixed effects or time-invariant variables as substitutes (i.e. AK), except a one year analysis (for example, HHM and G) or the use of average value of variables over the whole period considered (dJKN and KK).

Many differences among studies also emerge in the measurement of the dependent variable. Market leverage is used when the samples include listed companies, either alone or together with the book measure; when the samples include unlisted companies, the book leverage is measured.

As far as the composition of leverage is concerned, two aspects seem to be important:

- firstly, the nature of debt included in measuring leverage: either a total indebtedness formulation (more frequently adopted), including financial and non-financial debt (i.e. account payables and provisions for pensions or deferred expenses funds), or a financial leverage measure;

- secondly, the composition of the term structure: either only long-term debt (more frequently used) or long and short term debt together or in separate regressions.

While financing policies seem to have similar patterns of behavior around the world (i.e. the debt ratios seem to be affected in the same way and by the same type of variables), despite the evident institutional differences (Rajan \& Zingales, 1995; Booth et al., 2001), many studies on country effect emphasize that country macroeconomic, financial and institutional factors may have an important influence on capital structure, and that these effects on leverage are both direct and indirect, which means that country variables both affect the leverage levels of firms and play a moderating role in the relationship between leverage and its firm-level and industry-level determinants. Giannetti (2003) points out that the across-country similarity of financing behavior emerging from some studies is apparent and seems due to the bias induced by their using samples of large listed companies: in fact, large listed companies have easier access to international financial markets and, for this reason, institutional, financial, and macroeconomic peculiarities of their domestic markets less influence their corporate finance decisions.

The most frequently used country characteristics are discussed below and a short review of the reasoning supporting their impact on leverage is presented in parallel: we discuss the relationships that result more supported by the empirical findings considered here, also highlighting more meaningful exceptions. 
Table 1. A review of the main empirical studies on country effect (from 2000 to date)

\begin{tabular}{|c|c|c|c|c|c|c|c|c|c|c|c|c|}
\hline \multirow[t]{2}{*}{ study } & \multicolumn{3}{|c|}{ sample } & \multicolumn{2}{|c|}{ country effiect } & \multicolumn{3}{|c|}{ country determinants } & \multicolumn{3}{|c|}{ non-country determinants } & \multirow[t]{2}{*}{ dependent variable } \\
\hline & countries & $\begin{array}{c}\text { firms/ } \\
\text { observations }\end{array}$ & years & direct & indirect & institutional & financial system & macro-conomic & firm & industry & year & \\
\hline 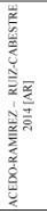 & $\begin{array}{c}5 \text { European } \\
\text { (France, } \\
\text { Germany, Italy, } \\
\text { Spain, UK) }\end{array}$ & $\begin{array}{l}888 \text { non- } \\
\text { financial } \\
\text { listed } \\
\text { companies } \\
6528 \text { firm- } \\
\text { year- } \\
\text { observations }\end{array}$ & $\begin{array}{l}{ }_{2008}^{1998-} \\
-\end{array}$ & $\begin{array}{l}\text { country dummies in } \\
\text { regression of full s sample }\end{array}$ & 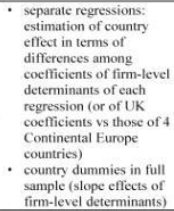 & & $\begin{array}{l}\text { kind of financial } \\
\text { system: bank-oriented } \\
\text { vs market-oriented }\end{array}$ & & $\begin{array}{l}- \text { effective tax rate } \\
\text { non-debt tax shieds } \\
\text { financial distress costs } \\
\text { size } \\
\text { free cash flow } \\
\text { incidence of fixed assets } \\
\text { (collateral) }\end{array}$ & & & $\begin{array}{l}\text { book leverage: total } \\
\text { debt divided by total } \\
\text { assets }\end{array}$ \\
\hline 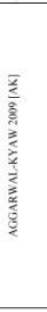 & $\begin{array}{l}14 \text { European } \\
\text { (Austria, } \\
\text { Belgium, } \\
\text { Dennark. } \\
\text { Finland, France, } \\
\text { Germany. } \\
\text { Ireland, tialy, } \\
\text { Netherlands. } \\
\text { Norway, Spain, } \\
\text { Sweden, } \\
\text { Switcerland, } \\
\text { UK) }\end{array}$ & $\begin{array}{l}4.056 \text { firms } \\
26.896 \text { firm- } \\
\text { year } \\
\text { observations }\end{array}$ & $\begin{array}{l}1990- \\
2003\end{array}$ & $\begin{array}{l}\text { country variables in the } \\
\text { regression model }\end{array}$ & omitted & 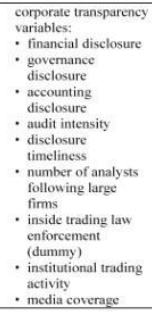 & $\begin{array}{l}\text { - banking sector } \\
\text { development } \\
\text { - stock mkt } \\
\text { development } \\
\text { (capitalization and } \\
\text { liquidity ratio) } \\
\text { bond mkt } \\
\text { development }\end{array}$ & $\begin{array}{l}\text { GDP per capita } \\
\text { g growh } \\
\text { inflation rate }\end{array}$ & 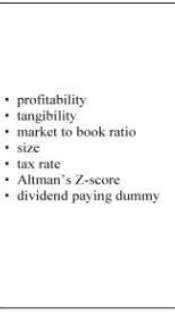 & $\begin{array}{l}\text { average } \\
\text { industry } \\
\text { sector } \\
\text { leverage }\end{array}$ & $\begin{array}{l}\text { not used: the } \\
\text { time-invariant } \\
\text { transparency } \\
\text { variables } \\
\text { serve as } \\
\text { substitutes }\end{array}$ & $\begin{array}{l}\text { - book leverage: total } \\
\text { debt included trade } \\
\text { debt and other } \\
\text { liabilitiess) divided by } \\
\text { total asses } \\
\text { - long term debt to total } \\
\text { assets }\end{array}$ \\
\hline 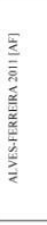 & $\begin{array}{l}31 \text { European: } 11 \\
\text { common law- } \\
\text { based and 12-4-4 } \\
\text { French, German, } \\
\text { Scandinavian } \\
\text { civil law-based }\end{array}$ & $\begin{array}{c}5.699 \text { listed } \\
\text { fims } \\
21.804 \text { firm- } \\
\quad \text { year } \\
\text { observations }\end{array}$ & $\begin{array}{l}1991- \\
2001 \\
\text { (firms } \\
\text { with at } \\
\text { least } \\
\text { five- } \\
\text { years) } \\
\text { indepen } \\
\text { dent } \\
\text { variable } \\
\text { s1 year } \\
\text { lag }\end{array}$ & $\begin{array}{l}\text { country variables in the } \\
\text { regression model }\end{array}$ & $\begin{array}{l}\text { interaction effects between } \\
\text { firm-specific variables and } \\
\text { dummy of legal system and } \\
\text { sharcholdect rights index } \\
\text { separate parameter } \\
\text { estimation for sub samples } \\
\text { per legal system, level of } \\
\text { sharcholder rights index. } \\
\text { developed ve emerging } \\
\text { countries }\end{array}$ & $\begin{array}{l}\text { - dummy of legal } \\
\text { system origin (civil } \\
\text { French, German and } \\
\text { Scandinavian law } \\
\text { and common law) } \\
\text { - shareholders' rights } \\
\text { index } \\
\text { - creditiors' rights } \\
\text { index } \\
\text { - corruption index }\end{array}$ & $\begin{array}{l}\text { - banking sector } \\
\text { development } \\
\text { - stock mkt } \\
\text { development } \\
\text { (liquidity ratio of } \\
\text { stock market) } \\
\text { - average number of } \\
\text { analysts }\end{array}$ & inflation rate & $\begin{array}{l}: \text { profitability } \\
: \begin{array}{l}\text { tangibility } \\
\text { market to book ratio } \\
\text { size } \\
\text { extemal finance weighted } \\
\text { average }\end{array}\end{array}$ & $\begin{array}{l}\text { industry } \\
\text { fixed } \\
\text { effects }\end{array}$ & $\begin{array}{l}\text { time fixed } \\
\text { effects }\end{array}$ & 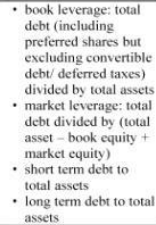 \\
\hline 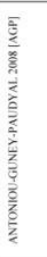 & $\begin{array}{l}5 \text { countries: } 2 \\
\text { market based } \\
\text { (UK and US) } \\
\text { and } 3 \text { bank- } \\
\text { based (France, } \\
\text { Germany, Japan) }\end{array}$ & $\begin{array}{l}4.854 \text { listed } \\
\text { firms } \\
57.134 \text { firm- } \\
\text { year } \\
\text { observations } \\
\text { (manufacturin } \\
\text { gand } \\
\text { services) }\end{array}$ & $\begin{array}{l}1987- \\
2000 \\
\text { (at least } \\
\text { 5 years } \\
\text { of data } \\
\text { for each } \\
\text { firm) }\end{array}$ & $\begin{array}{l}\text { country dummies or } \\
\text { country variables (time- } \\
\text { variant and time- } \\
\text { invariant) in the common } \\
\text { regression on the total } \\
\text { panel sample }\end{array}$ & 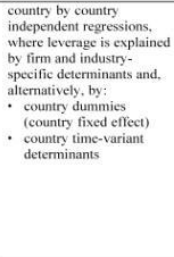 & $\begin{array}{l}\text { type of legal system } \\
\text { (common law vs civil } \\
\text { law): } \\
: \text { creditor rights } \\
\text { anti-director rights } \\
: \text { rule of law } \\
: \text { ownership } \\
\text { concentration }\end{array}$ & $\begin{array}{l}\text { - type of financial } \\
\text { system } \\
\text { - annual cquity } \\
\text { premium } \\
\text { term structure of } \\
\text { interest rate }\end{array}$ & $\begin{array}{l}\text { - M\&A activity at } \\
\text { country level }\end{array}$ & 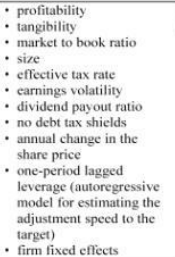 & $\begin{array}{l}\text { M\&A } \\
\text { activity at } \\
\text { industry } \\
\text { level }\end{array}$ & $\begin{array}{l}\text { time fixed } \\
\text { effects }\end{array}$ & $\begin{array}{l}\text { - book leverage: total } \\
\text { debt divided by total } \\
\text { asssts } \\
\text { market leverage: (otal } \\
\text { debt divided by book } \\
\text { total debt +market } \\
\text { value of equity) }\end{array}$ \\
\hline
\end{tabular}

\begin{tabular}{|c|c|c|c|c|c|c|c|c|c|c|c|c|}
\hline 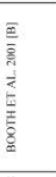 & $\begin{array}{l}10 \text { developing } \\
\text { countrics } \\
\text { (diversity of } \\
\text { financial system } \\
\text { and economic } \\
\text { factors) vs } 7 \\
\text { developed } \\
\text { countries }\end{array}$ & $\begin{array}{l}\text { aggregate data } \\
\text { regarding the } \\
\text { main firms in } \\
\text { each country } \\
\text { (727 firms) }\end{array}$ & $\begin{array}{l}1980- \\
1991\end{array}$ & $\begin{array}{l}\text { country dummies in a } \\
\text { common world model }\end{array}$ & $\begin{array}{l}\text { country by country } \\
\text { independent regressions, } \\
\text { where leverage is explained } \\
\text { by firm-specific } \\
\text { determinants }\end{array}$ & & $\begin{array}{l}\text { stock mkt } \\
\text { development } \\
\text { liquid } \\
\text { liabilities GDP }\end{array}$ & $\begin{array}{l}\text { GDP growth rate } \\
\text { inflation rate } \\
\text { statutory tax rate } \\
\text { (including rate } \\
\text { corporate and } \\
\text { personal tax } \\
\text { rates) : tax } \\
\text { advantage of debt }\end{array}$ & $\begin{array}{l}: \text { profitability } \\
\text { tangibility } \\
: \text { market to book ratio } \\
\text { size bet } \\
: \text { tax rate } \\
\text { business risk (std } \\
\text { devivation of earnings } \\
\text { before taxes over book } \\
\text { value of total assets) } \\
\text { firm fixed effect }\end{array}$ & & $\begin{array}{l}\text { time fixed } \\
\text { effects }\end{array}$ & $\begin{array}{l}\text { long term debt to long } \\
\text { term debt }+ \text { net worth } \\
\text { (total debt instead of } \\
\text { long term one for a } \\
\text { country; for } 7 \text { countries } \\
\text { also market leverages. } \\
\text { by substituting the } \\
\text { average equity market } \\
\text { value for net worth) }\end{array}$ \\
\hline 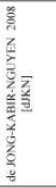 & $\begin{array}{l}42 \text { developed } \\
\text { and developing } \\
\text { countries }\end{array}$ & $\begin{array}{l}11.845 \text { firms } \\
\text { observations }\end{array}$ & $\begin{array}{l}1997- \\
2001 \text { (at } \\
\text { leas } 3 \\
\text { years of } \\
\text { data) }\end{array}$ & $\begin{array}{l}\text { country dummies } \\
\text { (intercept of acch country } \\
\text { regression where } \\
\text { dependent variable is } \\
\text { explained by firm-specific } \\
\text { variables) } \\
\text { effects of the country } \\
\text { variables on intercepts } \\
\text { abover }\end{array}$ & $\begin{array}{l}\text { country by country } \\
\text { independent regressions } \\
\text { (firm-specific determinants } \\
\text { of leverage) } \\
\text { coefficients of firm-specific } \\
\text { determinants of leverage } \\
\text { are regressed on country } \\
\text { variables }\end{array}$ & $\begin{array}{l}\text { - efficiency of judicial } \\
\text { system } \\
\text { : rule of law index } \\
\text { legality index } \\
\text { : compution index } \\
\text { shareholders' rights } \\
\text { index } \\
\text { - creditors' rights } \\
\text { index }\end{array}$ & $\begin{array}{l}\text { - type of financial } \\
\text { system: bank-based } \\
\text { versus market-based } \\
\text { (dummy) } \\
\text { - bond mkt } \\
\text { development } \\
\text { - stock mkt } \\
\text { development }\end{array}$ & $\begin{array}{l}\text { - GDP growth rate } \\
\text { capital formation }\end{array}$ & $\begin{array}{l}\text { - profitability } \\
\text { tangibility } \\
\text { market to book ratio } \\
\text { size to } \\
\text { tax rate } \\
\text { business risk (std } \\
\text { deviation of operating } \\
\text { income over book value } \\
\text { of totala assets during the } \\
\text { sample period) } \\
. \text { liquidity index }\end{array}$ & $\begin{array}{l}\text { industry } \\
\text { dummies }\end{array}$ & $\begin{array}{l}\text { average value } \\
\text { of variables } \\
\text { over the } 5 \\
\text { year period }\end{array}$ & $\begin{array}{l}\text { long term debt to } \\
\text { market value of total } \\
\text { assets (total asset - } \\
\text { book equity + market } \\
\text { equity) }\end{array}$ \\
\hline 要 & $\begin{array}{l}39 \text { developed } \\
\text { and developing } \\
\text { countries }\end{array}$ & $\begin{array}{l}36.767 \text { firms } \\
272.092 \text { firm- } \\
\text { year } \\
\text { observations }\end{array}$ & $\begin{array}{l}1991- \\
2006 \\
\text { firm and } \\
\text { country } \\
\text { variable } \\
\text { s1 } \\
\text { period } \\
\text { lagged }\end{array}$ & $\begin{array}{l}\text { country variables in full } \\
\text { sample regression and } \\
\text { sub-samples regressions } \\
\text { (each for developed and } \\
\text { developing countries) }\end{array}$ & omitted & $\begin{array}{l}\text { corruption index } \\
\text { common law } \\
\text { dummy } \\
\text { bankruptcy code } \\
\text { dummy }\end{array}$ & 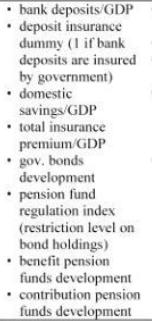 & $\begin{array}{l}- \text { developed } \\
\text { economy dummy } \\
\text { - inflation rate } \\
\text { - inflation rate } \\
\text { volatility } \\
\text { - statuory tax rate } \\
\text { (corporate } \\
\text { personal tax } \\
\text { rates) } \\
\text { tax treatment of } \\
\text { dividend } \\
\text { (dummy }=1 \text { for } \\
\text { countries with } \\
\text { either a full tax } \\
\text { system or a full } \\
\text { dividend } \\
\text { imputation } \\
\text { system; =0 } \\
\text { otherwise) }\end{array}$ & $\begin{array}{l}: \text { profitiability } \\
\text { tangibility } \\
\text { market to book ratio } \\
\text { size }\end{array}$ & $\begin{array}{l}\text { industry } \\
\text { dummics }\end{array}$ & $\begin{array}{l}\text { separate } \\
\text { regressions for } \\
\text { sub-pcriods } \\
\text { (1991-1998 } \\
\text { and 1999- } \\
2006)\end{array}$ & $\begin{array}{l}\text { - market leverage: } \\
\text { book value of } \\
\text { interest-bearing total } \\
\text { debt to market value } \\
\text { of the firm (total debt } \\
\text { + market talue of } \\
\text { equity + book value } \\
\text { of preferred stock) } \\
\text { - long-term debt/ otal } \\
\text { debt } \\
\text { - book leverage: total } \\
\text { deb/ total assets } \\
\text { - long term debthotal } \\
\text { assets } \\
\text { short term debtiotal } \\
\text { assets }\end{array}$ \\
\hline 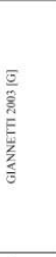 & $\begin{array}{l}8 \text { European } \\
\text { (Bcegium. } \\
\text { France. Ireland, } \\
\text { ltaly. } \\
\text { Netherlands. } \\
\text { Portugal. Spain. } \\
\text { UK) }\end{array}$ & $\begin{array}{l}61.557 \text { fimms } \\
\text { (listed and } \\
\text { unlisted; } \\
\text { median } \\
\text { number of } \\
\text { emploces= } \\
\text { about } 100 \text { ) } \\
\text { 228.675 firm- } \\
\text { year } \\
\text { observations }\end{array}$ & $\begin{array}{l}1993- \\
1997\end{array}$ & $\begin{array}{l}\text { firm-specific fixed eflects } \\
\text { (estimated in a single } \\
\text { regression on the total } \\
\text { pooled sample are } \\
\text { regressed to country time- } \\
\text { invariant explicative } \\
\text { variables }\end{array}$ & $\begin{array}{l}\text { country by country } \\
\text { independent regressions } \\
\text { (fim-specific variables as } \\
\text { determinants of leverage) } \\
\text { in a single regression on the } \\
\text { tolal pooled sample, the } \\
\text { interaction effects between } \\
\text { firm-specific variables, on } \\
\text { the one hand, and country } \\
\text { variables (institutional and } \\
\text { financial system related). } \\
\text { on the other hand }\end{array}$ & 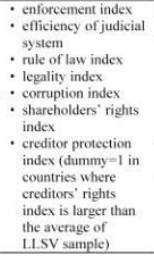 & $\begin{array}{l}\cdot \text { bond mkt } \\
\text { development } \\
\text { - bond mkt } \\
\text { capitalization } \\
\text { dummy ( }=1 \text { in } \\
\text { countries with } \\
\text { higher bond mkt } \\
\text { capitalization) } \\
\text { - stock mkt } \\
\text { development } \\
\text { - concentration of the } \\
\text { banking system } \\
\text { (sthare of assets of } \\
\text { the three largest } \\
\text { banks in a country) } \\
\end{array}$ & & $\begin{array}{l}\text { - profitability } \\
\text { maturity of assets (long- } \\
\text { term assets to total assets) } \\
\text { intangibility of assets } \\
\text { age (proxy of reputation) } \\
\text { size } \\
\text { growth rate of sales } \\
\text { gro deb tax shields } \times \text { tax } \\
\text { exhaustion dummy }(=1 \\
\text { for firms whose cash } \\
\text { flows } 0 \text { ) } \\
\text { - listed firm dummy } \\
\text { - firm fixed effects }\end{array}$ & $\begin{array}{l}\text { business } \\
\text { risk: std } \\
\text { deviation of } \\
\text { ROA at } \\
\text { industry } \\
\text { level }\end{array}$ & $\begin{array}{l}\text { cross-sectional } \\
\text { analysis in } \\
\text { year 1997 } \\
\text { panel data and } \\
\text { fim fixed } \\
\text { effects }\end{array}$ & $\begin{array}{l}\text { ratio of financial } \\
\text { debtst to the book } \\
\text { value of sharcholders. } \\
\text { funds } \text { financial } \\
\text { debsts } \\
\text { short term } \\
\text { debt financial debts }\end{array}$ \\
\hline 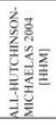 & $\begin{array}{l}8 \text { European } \\
\text { (Belgium. } \\
\text { Germany. Spain, } \\
\text { Ireland, tialy, } \\
\text { Netherlands. } \\
\text { Portugal, UK) }\end{array}$ & $\begin{array}{l}4.000 \text { SMEs } \\
\text { (fewer than } \\
200 \\
\text { employees) } \\
500 \text { cach from } \\
8 \text { countries }\end{array}$ & 1995 & country dummies & $\begin{array}{l}\text { country slope dummies } \\
\text { (caach for the firm-specific } \\
\text { variables) } \\
\text { country by country } \\
\text { independent reressions } \\
\text { (firm-specific determinants } \\
\text { of leveragec) }\end{array}$ & & & & $\begin{array}{l}\cdot \text { profitability } \\
\text { age } \\
\text { size } \\
\text { - growth rate of sales } \\
\text { fixed assets to total assets }\end{array}$ & & $\begin{array}{l}\text { cross-sectional } \\
\text { analysis }\end{array}$ & $\begin{array}{l}\text { short term debt to } \\
\text { total assets } \\
\text { - long term debt to total } \\
\text { assets }\end{array}$ \\
\hline 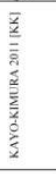 & $\begin{array}{l}40 \text { developed } \\
\text { and developing } \\
\text { countries }\end{array}$ & $\begin{array}{l}17.061 \text { listed } \\
\text { firms } \\
114.788 \text { firm- } \\
\text { year } \\
\text { observations }\end{array}$ & $\begin{array}{l}1997 . \\
2007\end{array}$ & $\begin{array}{l}\text { - hierarchical multilevel } \\
\text { model (HLM) countryy } \\
\text { industry, firm and time } \\
\text { effects are considered } \\
\text { as nested effects } \\
\text { - country level and } \\
\text { country-industry } \\
\text { interaction effects are } \\
\text { measured as random } \\
\text { intercepts }\end{array}$ & 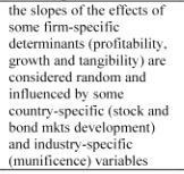 & & $\begin{array}{l}\text { type of financial } \\
\text { system: bank-based } \\
\text { versus market-based } \\
\text { (dummy) } \\
\text { (dund mkt } \\
\text { development } \\
\text { - stock mkt } \\
\text { development }\end{array}$ & GDP & $\begin{array}{l}\text { - profitability } \\
\text { size } \\
\text { Altman's Z-score } \\
\text { (distance from } \\
\text { bankruptcy) } \\
\text { growth }\end{array}$ & 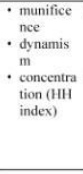 & $\begin{array}{l}\text { - time fixed } \\
\text { effect (yyar } \\
\text { dummies) at } \\
\text { firm level } \\
\text { - average value } \\
\text { of rariables } \\
\text { over the } \\
\text { period at } \\
\text { country and } \\
\text { industry level }\end{array}$ & $\begin{array}{l}\text { long term debt to } \\
\text { market value of total } \\
\text { assets (total asset - } \\
\text { book equity + market } \\
\text { equity) } \\
\text { book leverage as } \\
\text { robustness test }\end{array}$ \\
\hline
\end{tabular}




\subsection{Financial Characteristics}

This set of variables mainly refers to the development stage of a country's financial system and concerns the availability of a wider spectrum of sources of funds at lower cost. Banking system development and bond market development positively influence the firm's leverage: more borrowing options could be available and creditors could be more willing to lend at lower costs (AF found a negative relationship, however).

Stock market development negatively influences the firm's leverage, because broader supply of funds and lower information asymmetry between managers and investors decrease the cost of equity, and therefore determine a higher managers' propensity to issue equity to finance investments. However, the stock market turnover enhances creditors' willingness to lend, thanks to better opportunities to monitor the listed firms, or makes banks' funds more available to non-listed firms (see, for example, AK and AF).

Furthermore, we can consider the financial system structure as a determinant of leverage (dJKN and KK), since the understanding of the implications of the traditions of capital market-oriented and bank-oriented economies on the capital structure decision is important because they have direct implications on the sources of funds available to the corporate sector (AGP).

Two different perspectives are generally adopted. From a first standpoint, the type of financial system (i.e. market versus bank based) is related to the degree of ownership concentration of companies. Firms in market-based countries have a less concentrated ownership structure, while in bank-based countries the concentration is higher: if in an agency perspective, debt plays an important disciplinary role against managers' opportunistic behavior (Jensen, 1986), the firm's leverage is assumed to be higher in market-based countries. From a different standpoint, however, in bank-oriented countries, banks play a significant role in gathering the information and monitoring management; therefore, we expect better access to external borrowing and thus higher debt levels.

Purda (2008) shows that firms in bank-based systems are perceived to pose less risk than similar firms located in market-oriented environments. This is explained by two main characteristics of bank-based systems: $i$ ) bank debts represent inside debt, in the sense that a firm's close and specialized relationship with its bankers allows for the exchange of non-public information: access to this information allows banks to carefully monitor firm's management and scrutinize its behavior to ensure that it acts in the best interest of investors; ii) a second potential risk-reducing feature of bank-oriented financial systems is that banks become aware of repayment problems at an earlier stage and therefore can informally renegotiate credit terms rather than relying on formal bankruptcy procedures.

The more frequently indirect effects tested are the following:

1) the banking system development (or, simply, its orientation) mitigates the effect of bankruptcy costs on leverage, in terms of business risk, size, and tangibility;

2) the banking system development (or, simply, its orientation) mitigates the effect of agency costs on leverage, in terms of tangibility and growth;

3) the two mediation effects above can be performed by the bond market's development;

4) the stock market's development mitigates the effect of agency costs on leverage, in terms of tangibility and growth.

Fan et al. (2012) more explicitly consider the capital suppliers' perspective and preferences as determinants of the firm's capital structure choice, and include a set of supply-side variables in the leverage explanatory model, such as proxies of the supply of funds available to the various financial intermediaries like banks, pension funds and insurance companies. However, the impact of these variables result to be very weak.

\subsection{Institutional Characteristics}

All studies recognize the important role of the country's institutional characteristics in influencing corporate decisions on capital structure, although the impact of these variables, in general, is not so evident.

These determinants derive from La Porta et al. $(1997,1998,2000)$ approach, which assumes that the type of legal system (common versus civil law countries) affects both the content of the laws and the quality of their enforcement, and therefore the extent of legal protection of external investors. Since the conflicts of interest between corporate insiders (managers and/or majority shareholders) and external investors (minority shareholders and creditors) are important factors that influence the corporate financial structure, the extent to which contracts can be used to mitigate these incentive problems depends on the legal system and enforceability of these contracts. Countries based on common law would offer outside investors better protection than those 
based on civil law, resulting in a prevalence of outside equity vs. debt, and of longer vs. shorter debt. The type of legal system is generally broken into a set of institutional characteristics, such as creditors' right protection, shareholders' right protection (anti-director rights), quality of laws and regulations, and promptness of their enforcement.

Better protection of creditors and better legal enforcement mitigate the agency costs of debt, increasing the use of debt, and decreasing the negative impact of business risk and growth opportunities and the positive impact of tangibility on leverage. In addition, a good protection of creditors' rights helps to lengthen the debt maturity for firms with volatile returns $(\mathrm{G})$ : firms in sectors with highly volatile returns are more likely to default due to temporary illiquidity; longer debt maturities could help reducing inefficiencies in these sectors.

However, when we assume a demand-side perspective, better creditors' rights protection means higher cost of distress and bankruptcy for the borrowers, that should be more severely punished if they do not fulfill their debt obligations. In this scenario, firms might ask for less debt, discouraged by higher "actual" default costs: AGP found a negative impact of rule of law and dJKN of creditor protection on leverage.

Better protection of shareholders (Spamann, 2010) is likely to align the interests of the agent with those of the principal, reducing the agency benefits of debt and hence the firm's leverage. Conversely, when the agent-principal problem is less important: $i$ ) firms are likely to use more debt since the diversified shareholders' interests in exploiting tax shield value overtakes the risk-reducing perspective of managers and majority shareholders (who face both systematic and specific risks); $i$ ) the less information asymmetry increases the debt capacity of a firm (AGP). In addition, as far as closely held companies are concerned, if investors are more protected, control aversion makes the majority shareholders to prefer debt to equity.

Shareholders' protection mitigates the asset-substitution and underinvestment problems, and therefore lessens the negative impact of growth opportunities on leverage; however, for closely held companies, these problems are less relevant and majority shareholders, fearful of losing control, may prefer to use debt rather than equity and therefore ownership concentration should lead to high leverage for growing firms. In addition, when shareholders are less protected, more severe asymmetric problems occur and leverage is more sensitive to profitability ( $\mathrm{AF}$ and $\mathrm{dJKN}$ ).

When analyzing the protection of investors' rights, it is important to consider the mediation effect of the judicial context, that can enforce a tighter or weaker protection by the law system. A better judicial system means faster sentences, impartial and independent judges, and lower lawsuit costs. Therefore, a positive direct effect on leverage of quality of the judicial system could be expected, assuming the mandatory nature of debt contracts and the residual nature of shareholders' claims. Furthermore, the quality of the judicial system can moderate the degree of protection of investors' rights (we call this "actual" investor - shareholder or creditor - protection), enhancing the related direct effects on leverage.

The protection of creditors' rights is likely to moderate the impact on leverage of some firm-specific determinants; for example, a higher creditors' rights protection is likely to moderate the negative impact of operating risk and the positive effect of asset tangibility on financial leverage, reducing both (AF). This means that, when laws and their enforcement give a better protection to lenders, the bank system is likely to offer more credit to firms with poor collateral and volatile returns.

The corruption index, defined as the abuse of public office for private gain (FFT), reflects the extent to which corruption is perceived to exist among public officials and politicians. In the context of the firm's capital structure choices, the indicator proxies for the threat of investors' rights expropriation by managers or public officers. Debt is expected to be used relatively more than equity when the public sector is more corrupt, since it is easier to expropriate outside equity holders than debt holders. The enforcement of debt contracts, i.e. the number of days needed to enforce the respect of a debt contract (Djankov et al., 2007), or the presence/absence of an explicit bankruptcy code that regulates the resolution of default, specifying and limiting the rights and claims of creditors and facilitating the reorganization of the ongoing business (Djankov et al., 2007; FTT), affect the firm's leverage: poorly defined bankruptcy procedures and longer period to enforce a debt contract reduce the lenders' bargaining power against the borrowers, and therefore discourage the use of debt or make it more costly.

AK further detail the institutional setting of countries in terms of transparency level variations: they distinguish transparency that reduces owner-manager agency costs (i.e. number of analysts following large firms) from transparency that reduces owner-creditor agency costs and helps creditors control business risks (such as disclosure timeliness, institutional trading activity, and enforcement of anti-insider trading laws). They expect a negative impact of the first and positive of the latter on debt ratios. Other transparency measures such as 
financial disclosures and governance disclosures should be negatively associated with debt ratios and higher levels of audit intensity and accounting disclosures positively. All the above hypotheses are confirmed in a statistically significant way by the empirical findings.

\subsection{Macroeconomic Characteristics}

These country variables are less frequently used than others, or used more often as control variables. Among these variables, inflation rate and inflation rate volatility are the most widely used regressors of leverage. Investors would be less willing to lend if they are not sure about the real returns on their loans, i.e., if they face higher inflationary risk. On the other hand, if interest rates do not appropriately reflect the inflation rate, inflation can be associated with higher debt levels, since the real repayment value of debt declines with inflation. Inflation uncertainty increases the firm's business risk through volatility in the firm's selling prices, costs, and volume of sales; therefore, in a highly inflationary country with high inflation uncertainty, firms will experience high business risk and carry less debt in their capital structure.

As stated by Demirguc-Kunt and Maksimovic (1999), annual growth rate in national GDP is an indicator of the financing needs of firms, that triggers a positive effect on the use of debt. Capital formation can affect corporate leverage both positively and negatively: the accumulation of more retained earnings induces less dependence on debt usage, assuming the $\mathrm{POH}$ perspective; however, it could also generate more financial needs and therefore a higher need to use external sources of funds, i.e. more debt.

The tax system in general, and specifically the tax treatment of interest and dividend payments, has been recognized as an important factor influencing capital structure choices since the seminal work of Modigliani and Miller (1958). Some studies (B and FTT) include this determinant at the country level, rather than at the firm level. They use the country's statutory tax rate or the relative tax advantage of debt, considering both corporate and personal tax rates according to Miller's (1977) formulation, or, alternatively, the tax treatment of dividend, distinguishing between countries with dividend imputation or tax relief systems, on the one hand, and countries with classical tax systems, that double-tax corporate profits, on the other hand: in the latter, firms are expected to use more debt than in the former. Only FTT found a significant impact of tax policy on leverage.

\section{The Country Effect on the Corporate Capital Structure Choice: Some Critical Issues for Further Research}

Based on the previous review, we can highlight some critical issues, which should be taken in account in further research on the field.

\subsection{Sample Selection}

The international empirical studies generally adopt a broad set of countries and distinguish them along some general taxonomies like development level, type of financial systems, institutional origin, and so on, assuming (erroneously in our opinion) that countries within each category are homogeneous. On the contrary, if they differ in financial and/or institutional variables in a statistically significant way, the empirical evidence emerging from these studies (which use these general taxonomies as country determinants of leverage) underestimates the country effect and tells only a part of the story.

In order to demonstrate that, we consider a sample of about 800.000 non-financial (note 1) firms, over a ten year period (2000-2009), derived from the Bank for the Accounts of Companies Harmonized (BACH) and the European Sectoral references Database (ESD) projects (BACH-ESD): Table 2 shows that the classification of countries based on general taxonomies such as civil versus common law countries or bank-based versus market-based financial systems risk to consider homogeneous countries that are not. In fact, the seven countries included in our sample significantly differ from each other, although all classified as civil law countries and bank-based systems. The Kruskal-Wallis tests for both the institutional and financial characteristics of the seven countries considered in this case (and their average values) demonstrate that the mix of both the institutional and financial characters is different among the seven countries, although some similarities exist among them for individual variables of the two groups. For example, as far as the institutional characters are concerned, Austria and Germany belong to the same German-origin civil law group, but significantly differ in some aspects, such as corruption degree, law and judicial order, while they show the same values for the degree of protection of shareholders' and creditors' rights. Many differences also emerge among the 5 countries classified as French-origin civil law countries. For example, the shareholders' rights protection varies from a minimum of 2 (Belgium) to a maximum of 6 (Spain). Analogously, France and Italy show very distant degrees of corruption. More differences also emerge among these countries as far as their financial characteristics are concerned. For example, Germany, Italy and Portugal show a similar stock capitalization as a percentage of their 
GDP, but the number of their listed companies significantly differs. Analogously, their stock exchanges appear very different in terms of transaction volumes and consequent information asymmetry levels between investors and insiders.

Table 2. Differences among apparently homogeneous countries

\begin{tabular}{|c|c|c|c|c|c|c|c|c|c|}
\hline \multicolumn{6}{|c|}{ Institutional characteristics } & \multicolumn{4}{|c|}{ Financial characteristics } \\
\hline & SHARIGHTS & CREDRIGTHS & JUDIC & LAW & CORR & DLC & STOCKCAP & STOCKTURN & BANKPRIVCR \\
\hline chi-squared & 4829 & 4829 & 4829 & 4829 & 4829 & 4648 & 3111 & 3851 & 3948 \\
\hline df & 6 & 6 & 6 & 6 & 6 & 6 & 6 & 6 & 6 \\
\hline asint. sign. & 0.00 & 0.00 & 0.00 & 0.00 & 0.00 & 0.00 & 0.00 & 0.00 & 0.00 \\
\hline \multicolumn{10}{|c|}{ part $b$ - average values over 2000-2009 period } \\
\hline \multicolumn{6}{|c|}{ Institutional characteristics } & \multicolumn{4}{|c|}{ Financial characteristics } \\
\hline country & SHARIGHTS & CREDRIGTHS & JUDIC & LAW & CORR & DLC & STOCKCAP & STOCKTURN & BANKPRIVCR \\
\hline AUSTRIA & 4.00 & 3.00 & 9.50 & 10.00 & 2.35 & 97.70 & 28.91 & 39.74 & 87.65 \\
\hline BELGIUM & 2.00 & 2.00 & 9.50 & 10.00 & 2.90 & 182.90 & 68.067 & 42.61 & 72.34 \\
\hline FRANCE & 5.00 & 0.00 & 8.00 & 8.98 & 3.00 & 841.90 & 84.00 & 101.08 & 84.92 \\
\hline GERMANY & 4.00 & 3.00 & 9.00 & 9.23 & 1.94 & 703.10 & 47.81 & 139.34 & 82.99 \\
\hline ITALY & 4.00 & 2.00 & 6.75 & 8.33 & 5.25 & 285.90 & 43.15 & 123.62 & 80.94 \\
\hline PORTUGAL & 4.00 & 1.00 & 5.50 & 8.68 & 3.65 & 61.50 & 41.04 & 68.56 & 97.76 \\
\hline SPAIN & 6.00 & 2.00 & 6.25 & 7.80 & 3.35 & 2906.60 & 86.86 & 174.38 & 89.83 \\
\hline Total & 4.14 & 1.86 & 7.79 & 9.00 & 3.20 & 725.66 & 57.12 & 98.48 & 85.2 \\
\hline
\end{tabular}

Note. Sample of about 800.000 non-financial firms in 2000-2009 period from BACH-ESD dataset. SHARIGHTS and CREDRIGHTS measure the degree of protection of shareholders' and creditors' rights, respectively, according with Spamann (2010) and Djankov et al. (2007); JUDIC measures the efficiency and integrity of the judicial system, LAW assesses the law and order tradition of a country, CORR (Fan et al. 2012) measures the degree of government corruption. The stock market development considers both capitalization (STOCKCAP) and turnover (STOCKTURN) ratios, respectively measured as average market capitalization of listed companies as \% of GDP and total value of shares traded/average market capitalization ratio; the size of stock exchange list is the number of domestic listed companies (DLC) and the banking system development is measured in terms of the average domestic credit to private sector by banking sector as \% of GDP (BANKPRIVCR).

Furthermore, considering countries operating in very different economic and monetary systems risks that the effect of these macro-context differentials could distort the financial and institutional determinants' impact, especially when a larger sample of countries is used (as, for example, in dJKN, FTT and KK) and the possibility of controlling these differentials by means of the explanatory variables included in the regression model is likely to be limited.

In addition, using more apparently homogeneous countries (for example, only bank-based countries) allows to measure the financial leverage more realistically, considering for instance the short term bank debt, which represents a very important portion of financial debt, since it often disguises medium-long term debt by means of the tacit renewal mechanism; in bank-based countries, where corporate bonds are very marginally used as a source of funds, considering only the medium-long term debt (as usually done in the international studies which use very large and variegated country samples) implies the omission of the most financial liabilities.

On the contrary, a large and variegated sample of firms should be used, which variously differ in terms of size and industry, including small and non-listed firms, whose financial decisions are more subject to the institutional and financial constraints imposed by their domestic markets and therefore allows to better highlight the country effect, compared with studies whose samples just include large listed companies. This choice strengthens the model generalizability and the significance of the results: in many countries, in fact, large listed firms just represent a minor share of their countries' GDP and a small proportion of the existing firms.

\subsection{Determinants to Be Considered}

A broad set of determinants should be used, at firm, industry, and country level, breaking down each level in an ample set of variables that try to catch the different aspects of each level's impact on firms' leverage and avoiding dummies that categorize countries or industries in ex ante defined taxonomies, which could be heterogeneous within them. In studies here considered: i) firm determinants are largely detailed in the explanatory model; ii) country characteristics are generally included (HHM is an exception), but country 
dummies continue to play an important role in explaining the corporate leverage (for example, in AGP, B, dJKN, KK and AR); iii) industry effects are often included (in three studies are ignored), but are very rarely broken-down in analytical characteristics (KK is an exception). Breaking down industry in its features allows to consider industry effects time-variant and analytically show and discuss the various effects of industry on leverage. Furthermore, the more detailed the firm and industry determinants are, the more complete the analysis of the country's indirect effects can be.

The explanatory model of leverage should fit both the cross-sectional and the longitudinal variability of corporate leverage, and therefore avoids the use of average values of dependent and independent variables over time, as some studies do (see why in point $d$ of Section 3.4 below).

\subsection{Measurement of the Dependent Variable}

In measuring the dependent variable, many aspects should be considered (Venanzi, 2003 and 2010). There is no universally used measure of leverage. As Welch (2011) highlights, most researchers probably spend little time pondering their measures, and simply copy what their predecessors have adopted. A total indebtedness approach assumes that both managers and current and potential lenders look at the total debt of a firm to evaluate its financial risk. But it should be said that the non-financial liabilities are generally related to the specific firm's business and industry characteristics, and are not explicitly influenced by the determinants of the capital structure choice; for example, the accounts payable largely depends on both the industry practices in paying suppliers, and the intensity and/or stability of the firm relationships with them (which are significant, for example, in lean production systems and in industrial districts), and the provisions arising from labor market contracts or specific regulations are influenced by the human capital intensity of production.

In addition, in some countries (the European countries, for example) these non-financial liabilities (i.e. the provisions arising from labor market contracts or specific regulations) can have a major weight on the total sources of funds, distorting the measurement of financial leverage, when included.

Among the studies here considered, only two take in account these aspects: FTT consider only financial debt, but include in the denominator of the leverage ratio the total assets, therefore implicitly considering the non-financial debt as net worth; only G's financial leverage measure seems to be exempt from Welch's criticism.

Analogously, the most used long term debt ratio fails to explain a large part of firms' indebtedness, especially in bank-based countries, where the banks' short term debt often disguises medium-long term debt (by means of the tacit renewal mechanism, which allows lenders to control entrepreneurs' opportunistic behavior threating them of not renewing the loans), and corporate bonds are very marginally used as a long-term source of funds. Therefore, considering only the medium-long term debt implies the omission of the most financial liabilities (for example, among Continental Europe countries, from about one third of Belgium to two thirds of Italy).

As said before, using an ample set of countries does not allow a consistent leverage measurement to be adopted. However, it should be considered that the determinants of short term debt can partially differ from those of long term debt. In addition, it should be considered that the short-term debt often serves as a first instance source of funds for financing unexpected needs, and therefore could be inconsistent with the objective of explaining the target leverage, pursued by the firm in a long-term horizon, because contingent circumstances bias it. Therefore, some smoothing mechanisms of contingent volatility should be used.

Finally, it should be considered that the observed yearly static leverage measurements do not approximate the target leverage, since the adjustment costs can explain some temporary deviations of a firm from its optimal capital structure, within an acceptable range of non-adjustment (Myers, 1984, Fisher, Heinkel, \& Zeckner, 1989; Leary \& Roberts, 2005; Lemmon et al., 2008; Flannery \& Rangan, 2006). Furthermore, the yearly observed value of leverage for the small firms could be biased by financial constraints and therefore be not representative of the target levels chosen by the firms. It should be specified a dynamic model (among studies here considered, only AGP and AR adopt this approach), but taking in account that the evidence emerging from Leary-Roberts (2005), Lemmon et al. (2008), Flannery-Rangan (2006) and Hovakimian (2001 and 2004) shows that the target adjustment process is neither linear nor on a yearly basis. Alternatively, a some more robust measure of target leverage could be adopted, by aggregating homogeneous country-industry-year-firm observations along a dimension that mostly captures leverage variability within each country-industry-year combination (for example, leverage measured at size-class level).

The choice between book and market value of debt seems to not influence the empirical results significantly, according with Hovakimian et al. (2001). Bowman (1980) shows that the correlation between the book and market values of debt is very high. However, using the market value of equity in measuring leverage could 
introduce spurious correlations with determinants that include market value of firm, as for example the market to book ratio, often used as a proxy of growth, when managers choose debt equity ratio referring to book values. Furthermore, market leverage is subject to market volatility (AK).

\subsection{Test design and Methodology}

As far as test design and methodology are concerned, the country's impact on the capital structure choices should be analyzed in terms of both direct and indirect effects, in a model whose parameters are simultaneously estimated, including those of the firm- and industry-specific determinants. The country indirect effects should be expressed in terms of fully or partially mediated effects of the country characteristics on the impact on leverage of the firm- and industry- specific determinants. A simultaneous equations system (Greene, 2002) seems to be the best choice: it allows the evaluation, within a single model, of the overall set of relationships among all the variables, through the estimate of the variance and co-variance matrix of the entire system of equations and managing the possible endogeneity relationships among regressors, leading to consistent estimates of the parameters.

This methodology would prevent the potential bias of methodologies used in studies here considered. For example, the following:

a) the indirect effect is not considered at all (HHM, FTT and AK);

b) the direct and indirect effects are estimated with separate models (dJKN and G). These studies firstly estimate the direct effects, partially ignoring the indirect ones: country dummies but not their characteristics are used in estimation of the intercept and the slope of firm specific determinants. Therefore, slopes are regressed on country's characteristics: their omission in the first regression causes an incorrect specification of the model, producing biased estimates. Furthermore, if we estimate the country effect by using separate equations for each country or including country dummy variables in the same equation, we ignore the possible interaction among countries in estimating the coefficient of their characteristics: countries are different mix of characteristics, but these characteristics are likely to affect the leverage in the same way (rather more if countries belong to the same monetary and economic scenario);

c) the indirect effects are estimated by using interaction variables (AF and AGP). Using the product among variables as a proxy of the indirect effects ignores the possible causality relationships among regressors, producing inconsistent estimates of the model's parameters (Hayashi, 2000). The problem is even more relevant when we analyse the interactions among more than two variables, since the possible cause-effect relationships are obviously more complex. It should be better to use the mediational model approach (Mathieu \& Taylor, 2006), which is based on the analysis of causal sequences starting from the theoretical assumptions about the cause-effect relationships among the variables and it allows the evaluation of the existence, intensity, and direction of the effects;

d) time is often used as a first aggregation level of the observed data (KK, dJKN, G and HHM). The use of time as a first aggregation level of the observed data, like in the hierarchical linear model of KK or when averages over time of the dependent and independent variables are used $(\mathrm{dJKN})$, could lead to the consideration of cross-sectional subsets of observations, and therefore to the loss of the information related to the time variability of all the determinants involved in the model estimation in the subsequent aggregation levels. On the contrary, a test design which considers firm-year observations aims at estimating an explanatory model that averagely fits across years and firms. The hierarchical multilevel analysis, used in KK's study, absorbs the time variability at the first level, considering time as an explanatory level such as firm, industry and country levels: hence the impact on leverage of the other determinants (country and industry-specific) is implicitly assumed to be time-invariant.

Finally, we should point out that the expected sign of the impact of some determinants of leverage could be different, depending on the prevalence of the supply-side vs. the demand-side perspective. For example, the creditor's rights protection (discussed above) might positively affect leverage because lenders are likely to be more willing to supply financing, but, on the other hand, the impact can be negative, if we assume a demand-side perspective: firms will be more reluctant to borrow, fearing higher distress costs. The same differences could be observed in the indirect effect of the determinant, for example in mediating impacts of tangibility or business risk.

Analogously, as far as the inflation rate is concerned. From a supply-side perspective, in a highly inflationary country, investors will be less willing to lend, since they are not sure about the real returns on their loans; however, from a demand-side perspective, if interest rates do not adequately reflect the high inflation rate, 
inflation can be associated with higher debt levels because the real repayment value of debt declines with inflation.

In the international studies here considered the supply-side perspective seems to prevail in the hypotheses' formulation: therefore, empirical findings that show signs different from assumptions are considered abnormal.

In conclusion, the literature review here presented shows that the country's characteristics - institutional, financial, and macro-economic - significantly influence the capital structure of firms. However, nevertheless the large strand of international studies conducted on this field, some methodological criticisms make the empirical evidence not to be conclusive, requiring further research. Some suggestions have been provided here to improve this research.

\section{References}

Acedo-Ramirez, M. A., \& Ruiz-Cabestre, F. J. (2014). Determinants of Capital Structure: United Kingdom Versus Continental European Countries. Journal of International Financial Management \& Accounting, 25(3), 237-270. http://dx.doi.org/10.1111/jifm.12020

Aggarwal, R., \& Kyaw, N. N. A. (2009). International variations in transparency and capital structure: Evidence from European firms. Journal of International Financial Management \& Accounting, 20(1), 1-34. http://dx.doi.org/10.1111/j.1467-646X.2009.01025.x

Alves, P. F. P., \& Ferreira, M. A. (2011). Capital structure and law around the world. Journal of Multinational Finance Management, 21, 119-150. http://dx.doi.org/10.1016/j.mulfin.2011.02.001

Antoniou, A., Guney, Y., \& Paudyal, K. (2008). The determinants of capital structure: Capital market-oriented versus bank-oriented institutions. Journal of Financial and Quantitative Analysis, 43(1), 59-92. http://dx.doi.org/10.1017/S0022109000002751

Bancel, F., \& Mittoo, U. R. (2004). Cross-country determinants of capital structure choice: A survey of European Firms. Financial Management, winter, 103-132.

Booth, L., Aivazian, V., Demirguc-Kunt, A., \& Maksimovic, V. (2001). Capital structure in developing countries. Journal of Finance, 56(1), 87-130. http://dx.doi.org/10.1111/0022-1082.00320

Bowman, R. G. (1980). The Importance of a Market-Value Measurement of Debt in Assessing Leverage. Journal of Accounting Research, 18(1), 242-254. http://dx.doi.org/10.2307/2490400

De Jong, A., Kabir, R., \& Nguyen, T. T. (2008). Capital structure around the world: The role of firm- and country-specific determinants. Journal of Banking \& Finance, 32, 1954-1969. http://dx.doi.org/10.1016/j.jbankfin.2007.12.034

Demirguç-Kunt, A., \& Maksimovic, V. (1999). Institutions, Financial Markets and Firms' Choice of Debt Maturity. Journal of Financial Economics, 54, 295-336. http://dx.doi.org/10.1016/S0304-405X(99)00039-2

Djankov, S., McLiesh, C., \& Shleifer, A. (2007). Private credit in 129 countries. Journal of Financial Economics, 84, 299-329. http://dx.doi.org/10.1016/j.jfineco.2006.03.004

Fan, J. P. H., Titman, S., \& Twite, G. (2012). An international comparison of capital structure and debt maturity choices. Journal of Financial and Quantitative Analysis, 47(1), 23-56. http://dx.doi.org/10.1017/S0022109011000597

Fischer, E. O., Heinkel, R., \& Zechner, J. (1989). Dynamic capital structure choice: Theory and tests. Journal of Finance, 44(1), 19-40. http://dx.doi.org/10.1111/j.1540-6261.1989.tb02402.x

Flannery, M. J., \& Rangan, K. (2006). Partial adjustment towards target capital structures. Journal of Financial Economics, 79(3), 469-506. http://dx.doi.org/10.1016/j.jfineco.2005.03.004

Giannetti, M. (2003). Do better institutions mitigate agency problems? Evidence from corporate finance choices. Journal of Financial and Quantitative Analysis, 38(1), 185-212. http://dx.doi.org/10.2307/4126769

Green, H. W. (2002). Econometric Analysis (5th ed.). New Jersey: Prentice Hall.

Hall, G. C., Hutchinson, P. J., \& Michaelas, N. (2004). Determinants of the capital structures of European SMEs. $\begin{array}{llll}\text { Journal of Business Finance \& Accounting, } & \text { 31(5-6), }\end{array}$ http://dx.doi.org/10.1111/j.0306-686X.2004.00554.x

Hayashi, F. (2000). Econometrics. Princeton: Princeton University Press

Hovakimian, A. (2004). The Role of Target Leverage in Security Issues and Repurchases. Journal of Business, 
77(4), 1041-1072. http://dx.doi.org/10.1086/422442

Hovakimian, A., Opler, T., \& Titman, S. (2001). The debt-equity choice. Journal of Financial and Quantitative Analysis, 36(1), 1-24. http://dx.doi.org/10.2307/2676195

Jensen, M. (1986). Agency costs of free cash flow, corporate finance and takeovers. American Economic Review, 76, 323-339.

Kayo, E. K., \& Kimura, H. (2011). Hierarchical determinants of capital structure. Journal of Banking \& Finance, 35, 358-371. http://dx.doi.org/10.1016/j.jbankfin.2010.08.015

La Porta, R., Lopez-De-Silanes, F., Shleifer, A., \& Vishny, R. (1997). Legal Determinants of External Finance. Journal of Finance, 52, 1131-1150. http://dx.doi.org/10.1111/j.1540-6261.1997.tb02727.x

La Porta, R., Lopez-De-Silanes, F., Shleifer, A., \& Vishny, R. (1998). Law and finance. Journal of Political Economy, 106, 1113-1155. http://dx.doi.org/10.1086/250042

La Porta, R., Lopez-de-Silanes, F., Shleifer, A., \& Vishny, R. (2000). Investor protection and corporate governance. Journal of Financial Economics, 58, 3-27. http://dx.doi.org/10.1016/S0304-405X(00)00065-9

Leary, M. T., \& Roberts, M. R. (2005). Do firms rebalance their capital structures? Journal of Finance, 60(6), 2575-2619. http://dx.doi.org/10.1111/j.1540-6261.2005.00811.x

Mathieu, J. E., \& Taylor, S. R. (2006). Clarifying conditions and decision points for mediational type inferences in organizational behavior. Journal of Organizational Behavior, 27, 1031-1056. http://dx.doi.org/10.1002/job.406

Miller, M. H. (1977). Debt and taxes. Journal of Finance, 32(2), 261-275. http://dx.doi.org/10.2307/2326758

Modigliani, F., \& Miller, M. H. (1958). The cost of capital, corporation finance and the theory of investment. American Economic Review, 48, 261-297.

Myers, S. (1984). The capital structure puzzle. Journal of Finance, 39, 574-592. http://dx.doi.org/10.2307/2327916

Purda, L. D. (2008). Risk perception and the financial system. Journal of International Business Studies, 39, 1178-1196. http://dx.doi.org/10.1057/palgrave.jibs.8400411

Rajan, R., \& Zingales, L. (1995). What do we know about capital structure? Some evidence from international data. Journal of Finance, 50, 1421-1460. http://dx.doi.org/10.1111/j.1540-6261.1995.tb05184.x

Spamann, H. (2010). The "Antidirector Rights Index" Revisited. The Review of Financial Studies, 23(2), 467-486. http://dx.doi.org/10.1093/rfs/hhp067

Venanzi, D. (2010). Il puzzle della struttura finanziaria. Milan: Pearson Italia.

Venanzi, D. (ed.) (2003). Le decisioni di struttura finanziaria delle imprese italiane - Evidenza empirica. Perugia: Morlacchi Editore.

Welch, I. (2011). Two common problems in capital structure research: The financial-debt-to-asset ratio and issuing activity versus leverage changes. International Review of Finance, 11(1), 1-17. http://dx.doi.org/10.1111/j.1468-2443.2010.01125.x

\section{Notes}

Note 1. The firms belong to 23 industries of the secondary and tertiary sectors, following the NACE (Nomenclature statistique des activités économiques dans la Communauté européenne) classification: 15 manufacturing industries, 3 energy, water supply and construction industries, 3 wholesale and retail trade industries, and 2 service industries (transportation and accommodation, and food services).

\section{Copyrights}

Copyright for this article is retained by the author(s), with first publication rights granted to the journal.

This is an open-access article distributed under the terms and conditions of the Creative Commons Attribution license (http://creativecommons.org/licenses/by/4.0/). 